\title{
Analysis of the influence of environmental change on river runoff in Loess Plateau of China
}

\author{
Yong Jing ${ }^{1,2}$ and Zuhao Zhou ${ }^{1}$ \\ ${ }^{1}$ China Institute of Water Resources and Hydropower Research, Beijing, 100038, China \\ ${ }^{2}$ Hydrology and Water Resources Survey Bureau of Shaanxi Province, Xi' an, 710068, China
}

Correspondence: Yong Jing (yong.j@126.com) and Zuhao Zhou (zhzh@iwhr.com)

Published: 16 September 2020

\begin{abstract}
The double interaction between climate change and human activity affects the changes in the environmental conditions of catchment runoff and confluence. Using 1956-2012 57 years of river runoff series data of 27 rivers in hilly gully area of Loess Plateau in Shaanxi province 39 hydrological station data, reduction of social and economic water consumption, plotting the annual precipitation and annual runoff double cumulative curve of annual runoff flow series consistency test, the consistency processing of annual runoff data and the quantitative analysis of its influence were also made. The results show that: the consistency of annual runoff data sequence of 21 hydrological stations is affected by the change of environmental conditions of runoff generation and confluence, and the turning point (year) and the degree of impact can be divided into three situations or three periods. One is the 12 station in 2000 after the annual runoff system is small; Two, there are 4 stations before and after in 1970, the annual precipitation and annual runoff double cumulative curve is obviously turning point. Before the turning point, a series of systems has a large high production period. After turning, it shows that a series of systems with low runoff yield caused by the Changes in environmental conditions of runoff and confluence in the underlying surface and climate and so on; the three is to have 5 stations occurred both before and after the 1970 high low flow period of the transition period in 2000, and after the annual runoff series of small low again.
\end{abstract}

\section{Foreword}

In China, the observed annual runoff of the Yellow River, Haihe River and the Pearl River has decreased sharply, the trend of drought and flood has intensified (Zhang et al., 2012), and the research upsurge of climate change and human activities affecting the runoff variation in the river basin has lasted for more than 10 years (Hui et al., 1993; Jing et al., 2008a-d; Jing, 2016; Peng, 2016; Wang et al., 2001, 2012; Zhang et al., 2012; Zhu et al., 2008). The quantitative study of the effects of climate factors and human activities, in particular various human activities, on the runoff of rivers undoubtedly contributes to the scientific evaluation of increasingly strained water resources and their exploitation and utilization, It is of great significance to support social economic and political development and the construction of ecological civilization.

The present quantitative analysis of climate factors and the changes of the environmental conditions of the catchment production and confluence made up of human activities are summarized. The methods of thinking which affect the river runoff (Hui et al., 1993; Jing et al., 2008a, b, d; Jing, 2016; Peng, 2016; Wang et al., 2001, 2012; Zhang et al., 2012; Zhu et al., 2008) are more consistent : In the long series of hydrological data, the short series of "natural runoff"in the period of high yield flow on the underlying surface of the original ecology with slight influence on early human activities were classified. This requires finding a turning point (year) in the impact of strong human activities; and then using the "underlying surface of the primordial" high-yielding "natural"runoff data as a "baseline". The difference between the recent runoff data of "current underlying surface" and that of low-yield runoff is the comprehensive influence value of the environmental change of watershed runoff. Finally, on the basis of data and methods, the climate factors and human activities can be separated from this comprehensive ef- 
fect value, and all kinds of factors of the effect of human activity can also be analyzed.

Taking the study area of Loess Plateau in the northern part of Shaanxi Province as an example, the time-series cumulative value correlation curve method is used in this paper. This paper analyzes and proves the great influence of the great change of environmental conditions on the abortion and confluence of river path: the "present condition underlying surface" of low yield water in the basin has been irreversible to the "primordial underlying surface" of its early high yield water. The hydrological data monitored under the condition of high yield water in the early stage of "original ecological underlying surface" no longer have the basis of "consistency of underlying surface" of "low yield water" in the near future, and three kinds of influence conditions are analyzed and summarized. In this paper, three kinds of correction methods of the "consistency" of the current underlying surface are proposed for the source of the data. On this basis, the comprehensive influence of environmental change on river runoff is analyzed quantitatively.

The research area is the central part of China's Loess Plateau and an important national energy and chemical base. In this area, the gullies are developed, the topography is broken, the precipitation is less, and the water resources are poor, so it is the most serious and important area of soil and water loss in history. The whole area is about $93000 \mathrm{~km}^{2}$, the population is 5.635 million people, the annual GDP scale is about CNY 385.6 billion, the annual output value of agriculture, forestry, animal husbandry and fishery industry is about CNY 48.67 billion. Since the 1960s and 1970s, the massive soil and water loss control has continued to this day, with the rapid development of modern energy and chemical industry park and urbanization, the development and utilization of regional soil and water mineral energy resources, as well as the geomorphological and hydrogeological conditions of the underlying surface of natural production and confluence in the basin are deeply affected.

\section{Research methods and data sources}

\subsection{Research methods}

Covering the hilly and gully region of the Loess Plateau in Shaanxi, a 57-year series from 1956 to 2012 of the annual runoff data of 39 hydrologic stations on 27 rivers were selected. The series of runoff data are calculated by "reduction" of the amount of water consumed directly by human society year by year, and the method and steps of 57-year series consistency check and correction are adopted, To comprehensively study and verify the effects of long-term largescale human activities on the gradual accumulation of runoff production and confluence on the underlying surface of the basin, and the changes of climatic factors such as precipitation, which have a dual interaction with each other, And finally, the environmental conditions of runoff production and confluence in the river basin will result in a turning point change of low yield flow under the "current underlying surface", and make the river runoff decrease.

Data preprocessing: under the condition that the condition of the underlying surface of the river basin remains consistent, the annual river runoff series should be kept basically consistent after the amount of river water consumed directly by human society is "reduced" to the measured amount of water measured by the hydrologic station. Before analyzing and judging whether the consistency of annual river runoff series is destroyed by the change of underlying surface, we should carry out the "reduction" of the direct consumption of river water by human society by the measured data of hydrologic station. As far as possible, the actual annual runoff of the hydrological section can reflect the "true value" of the current year's runoff yield and confluence of the watershed, that is, the "reduction calculation" of the "true value" of the measured annual runoff in the current year. The "reduction calculation" adopts the method of investigation and analysis of agricultural irrigation, industry, urban and rural life, reservoir water storage variables and the amount of water diversion across the river basin by means of the itemized investigation and reduction method.

By using the method of subdivision investigation and reduction: $W_{\text {natural }}=W_{\text {measured }}+W_{\text {irrigation }}+$ $W_{\text {industrial }}+W_{\text {urban life }}+W_{\text {rural life }}+W_{\text {reservoir storage variable }} \pm$

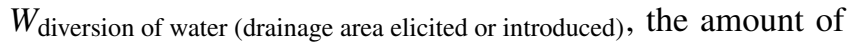
water consumed by human society is added to the measured value of hydrology, that is, the natural river runoff is reduced to "natural river runoff". Year by month, agricultural irrigation, industry, urban and rural life, reservoir water storage variables and cross-basin water diversion are investigated and calculated month by month, forming the series of "natural river runoff" after the reduction of human society's consumption of river water by every hydrological station from 1956 to 2012. In order to further analyze whether the underlying surface and other environmental factors have an impact on its series.

\subsection{Data sources}

39 hydrological station, 95 precipitation station from 1956 to 2012, 57 years monitoring data, analysis and calculation and involves a large number of agricultural irrigation, industrial and urban life, reservoir storage and inter-basin water transfer variable water volume, water and soil conservation engineering construction status and the related data, such as social economic indicators from the author of nearly 30 years in the handbook of shaanxi province hydrology, the shaanxi province water resources investigation and water resources in Shanxi Province and other preparation work, the relevant government water conservancy, statistics, meteorological departments to collect, textual research and practical investigation data accumulation. 

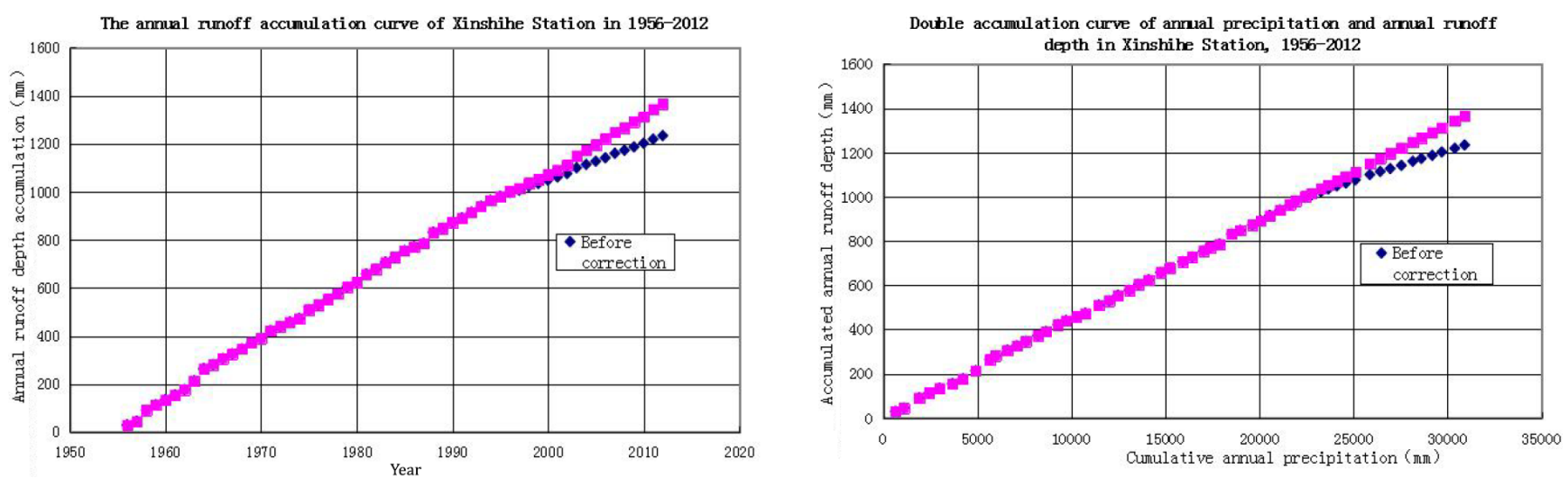

Figure 1. Annual runoff accumulation and double accumulation curve of annual precipitation runoff at Shenmu station.

Table 1. Statistical tables of small hydrological stations in the annual runoff series system around 2000 (Data Series 1956-2012).

\begin{tabular}{|c|c|c|c|c|c|c|c|c|c|}
\hline \multirow[t]{2}{*}{$\begin{array}{l}\text { Hydrologic } \\
\text { station }\end{array}$} & \multirow{2}{*}{$\begin{array}{l}\text { Series of } \\
\text { damage } \\
\text { turning } \\
\text { points } \\
\text { (year) }\end{array}$} & \multicolumn{2}{|c|}{$\begin{array}{l}\text { Series of damage } \\
\text { turning points (years) } \\
\text { before the series }\end{array}$} & \multicolumn{2}{|c|}{$\begin{array}{l}\text { Series of damage } \\
\text { turning points (years) } \\
\text { after the series }\end{array}$} & \multirow{2}{*}{$\begin{array}{r}\text { Correction of } \\
\text { the annual } \\
\text { mean runoff } \\
\text { in the same } \\
\text { period after } \\
\text { the break } \\
\text { year }(\mathrm{mm})\end{array}$} & \multicolumn{2}{|c|}{$\begin{array}{l}\text { After the destruction } \\
\text { turning point (year) series }\end{array}$} & \multirow[b]{2}{*}{$\begin{array}{r}\text { Annual } \\
\text { precipitation } \\
\text { increased } \\
\text { or decreased } \\
(\%)\end{array}$} \\
\hline & & $\begin{array}{r}\text { Annual runoff } \\
\text { depth mean } \\
(\mathrm{mm})\end{array}$ & $\begin{array}{r}\text { Annual mean } \\
\text { precipitation } \\
(\mathrm{mm})\end{array}$ & $\begin{array}{r}\text { Annual runoff } \\
\text { depth mean } \\
(\mathrm{mm})\end{array}$ & $\begin{array}{r}\text { Annual mean } \\
\text { precipitation } \\
(\mathrm{mm})\end{array}$ & & $\begin{array}{r}\text { Average annual } \\
\text { mean value of } \\
\text { uncorrected runoff } \\
\text { is less than that } \\
\text { before the revised } \\
\text { series }(\%)\end{array}$ & $\begin{array}{r}\text { Annual } \\
\text { precipitation } \\
\text { increased } \\
\text { or decreased } \\
(\%)\end{array}$ & \\
\hline HuangPu & 1999 & 49.6 & 385.8 & 11.5 & 379.6 & 46.5 & -76.8 & -1.6 & -6.3 \\
\hline WangDaoHengTa & 1996 & 56.7 & 378.9 & 19.3 & 350.7 & 56.8 & -66.0 & -7.4 & 0.2 \\
\hline ShenMu & 1998 & 70.4 & 399.2 & 24.3 & 381.3 & 67.1 & -65.5 & -4.5 & -4.7 \\
\hline WenJiaChuan & 1996 & 77.2 & 406.7 & 26.7 & 383.1 & 68.7 & -65.4 & -5.8 & -11.0 \\
\hline XinShiHe & 1995 & 24.7 & 554.2 & 15.0 & 516.2 & 22.3 & -39.3 & -6.9 & -9.7 \\
\hline CaoPing & 1996 & 48.0 & 456.7 & 24.9 & 451.7 & 46.3 & -48.1 & -1.1 & -3.5 \\
\hline ZiChang & 2003 & 47.6 & 493.3 & 28.3 & 519.4 & 47.5 & -40.5 & 5.3 & -0.2 \\
\hline YanChuan & 2003 & 44.1 & 448.3 & 27.8 & 468.4 & 45.7 & -37.0 & 4.5 & 3.6 \\
\hline YanAn & 2003 & 42.7 & 484.8 & 23.8 & 441.0 & 38.8 & -44.3 & -9.0 & -9.1 \\
\hline GanGuYi & 2003 & 38.4 & 506.6 & 24.9 & 471.4 & 36.1 & -35.2 & -6.9 & -6.0 \\
\hline DaCun & 1996 & 37.8 & 563.0 & 23.6 & 523.9 & 33.6 & -37.6 & -6.9 & -11.1 \\
\hline DanShi & 2000 & 41.9 & 375.8 & 25.3 & 415.6 & 43.1 & -39.6 & 10.6 & 2.9 \\
\hline
\end{tabular}

\section{Result analysis and discussion}

\subsection{Consistency analysis of annual river runoff series based on environmental change}

After the amount of water consumed by human society is "reduced" to the measured amount of water, in general, the annual river runoff series should be kept consistent basically, but the mechanism that the underlying surface condition affects the consistency of runoff production and confluence is complicated and the process is long. It is very difficult to judge and quantitatively calculate its influence. Through the upstream and downstream balance check of the river runoff after the "actual measurement and reduction of the amount of water consumed by human society", and the comparative analysis of the trunk and tributaries, the double and single accumulative curves of the annual precipitation and the annual runoff of 39 hydrologic stations are drawn. The results show that the consistency of the annual runoff data series at 21 stations is broken by the change of the environmental conditions of runoff production and confluence, the damage turning point (year) and the influence degree can be divided into three situations.

1. the slope of the cumulative curves of the 12 stations, such as Shenmu River, slowed significantly after 2000, showing that the annual runoff sequence system was smaller. The details are Fig. 1 and Table 1.

2. the double accumulation curve of annual precipitation runoff of 4 stations had a significant turning point around 1970, and the series before the turning point showed a large and systematic high-yield flow period. After turning, a series of low yield periods are shown as a result of the change of environment conditions such as underlying surface and climate. See Fig. 2 and Table 2 for details. 
Annual runoff cumulative curve of HengShan station 1956-2012

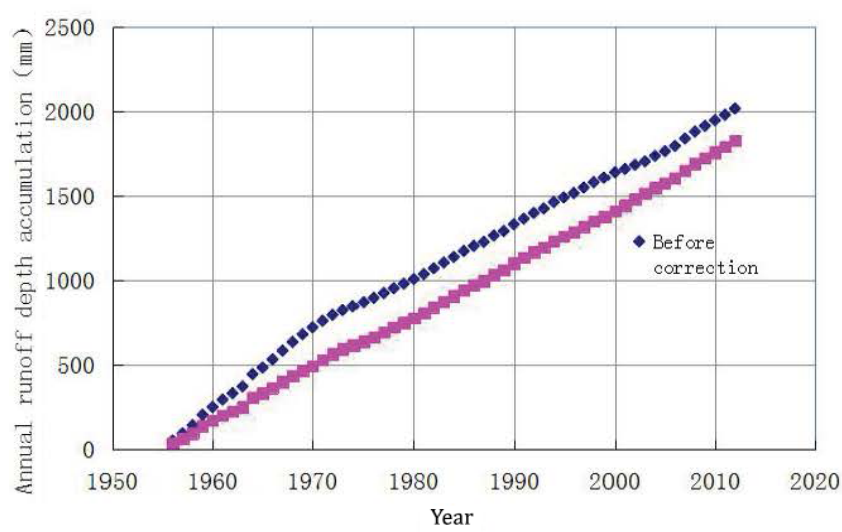

Double cumulative curve of annual precipitation runoff in HengShan station from 1956 to 2012

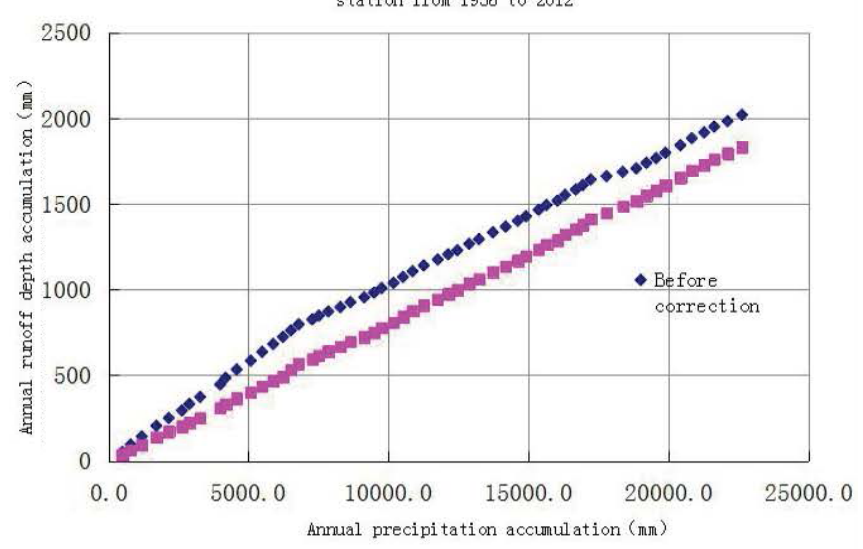

Figure 2. Annual runoff accumulation and double accumulation curve of annual precipitation runoff at Hengshan station.

Table 2. Statistical tables of small hydrological stations in the annual runoff series system around 1970 (Data Series 1956-2012).

\begin{tabular}{|c|c|c|c|c|c|c|c|c|c|}
\hline \multirow[t]{2}{*}{$\begin{array}{l}\text { Hydrologic(al) } \\
\text { station }\end{array}$} & \multirow{2}{*}{$\begin{array}{l}\text { Series of } \\
\text { damage } \\
\text { turning } \\
\text { points } \\
\text { (year) }\end{array}$} & \multicolumn{2}{|c|}{$\begin{array}{l}\text { Series of damage } \\
\text { turning points (years) } \\
\text { before the series }\end{array}$} & \multicolumn{2}{|c|}{$\begin{array}{l}\text { After the destruction } \\
\text { turning point (year) } \\
\text { series }\end{array}$} & \multirow{2}{*}{$\begin{array}{r}\text { Correction of } \\
\text { the mean annual } \\
\text { runoff depth } \\
\text { after the } \\
\text { high-yield } \\
\text { current period } \\
\text { before the } \\
\text { breakage } \\
\text { turning } \\
\text { point }(\mathrm{mm})\end{array}$} & \multicolumn{2}{|c|}{$\begin{array}{l}\text { Series of damage } \\
\text { turning points } \\
\text { (years) ago }\end{array}$} & \multirow{2}{*}{$\begin{array}{r}\text { Difference of the } \\
\text { average annual } \\
\text { runoff of the } \\
\text { revised series } \\
\text { ratio of high-yield } \\
\text { current period } \\
\text { "after the } \\
\text { destruction } \\
\text { turning } \\
\text { point" } \\
(\%)\end{array}$} \\
\hline & & $\begin{array}{r}\text { Annual } \\
\text { runoff } \\
\text { depth } \\
\text { mean } \\
(\mathrm{mm})\end{array}$ & $\begin{array}{r}\text { Annual } \\
\text { mean } \\
\text { precipitation } \\
(\mathrm{mm})\end{array}$ & $\begin{array}{r}\text { Annual } \\
\text { runoff } \\
\text { depth } \\
\text { mean } \\
(\mathrm{mm})\end{array}$ & $\begin{array}{r}\text { Annual } \\
\text { mean } \\
\text { precipitation } \\
(\mathrm{mm})\end{array}$ & & $\begin{array}{r}\text { Average annual } \\
\text { runoff depth } \\
\text { of the modified } \\
\text { high-yield flow } \\
\text { period series is } \\
\text { lower than that } \\
\text { of the pre- } \\
\text { correction } \\
\text { period (\%) }\end{array}$ & $\begin{array}{r}\text { Annual } \\
\text { precipitation } \\
\text { over the } \\
\text { same period } \\
(\mathrm{mm})\end{array}$ & \\
\hline HengShan & 1970 & 48.2 & 415.4 & 30.9 & 390.3 & 32.8 & -32.0 & 415.4 & 6.1 \\
\hline JingJiaGou & 1970 & 52.1 & 445.3 & 40.1 & 391.0 & 44.2 & -15.2 & 445.3 & 10.2 \\
\hline QingYangCha & 1970 & 55.8 & 459.6 & 40.2 & 432.1 & 43.1 & -22.8 & 459.6 & 7.2 \\
\hline BaiJiaCha & 1970 & 52.8 & 484.4 & 36.9 & 447.8 & 38.3 & -27.5 & 484.4 & 3.8 \\
\hline
\end{tabular}

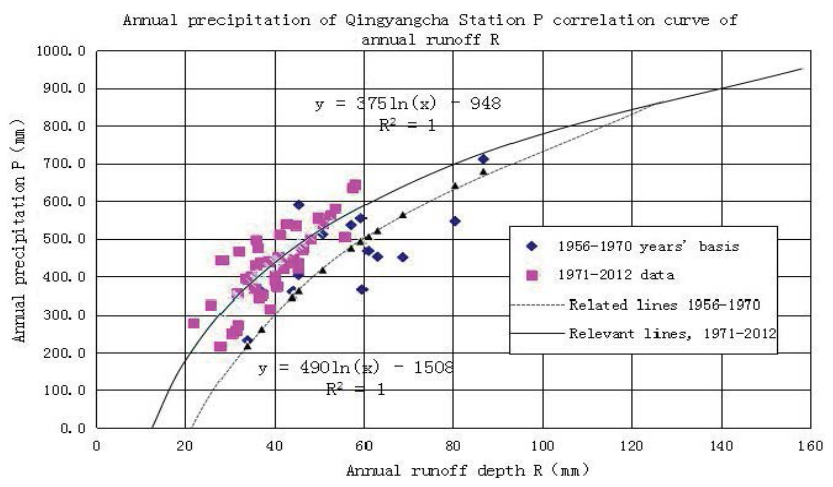

Figure 3. Relationship between annual precipitation and runoff at Qingyangcha station.

Figure 3 of the relationship between annual precipitation and annual runoff at Qingyangcha station also shows that in the same order of magnitude of annual precipitation, the an- nual runoff of the 1956-1970 series before 1970 is higher than that of the later series 1971-2012. It is necessary to revise the annual runoff of the high-yield flow period of "primordial underlying surface" with slight disturbance of human activities to the period of low-yield flow under the environment of "current underlying surface" after the change of strong human activities and climate factors, in order to maintain the consistency of environmental conditions of production and confluence (see Sect. 3.2).

3. In five stations, a turning point occurred in the period of high and low runoff of "primordial underlying surface" around 1970, and after 2000, the annual runoff series system in the environment of "current underlying surface" was again smaller than the low yield period, as shown in Fig. 4 and Table 3, respectively. 
Table 3. Statistical tables of small hydrological stations in the annual runoff series system around 1nd 2000 (Data series 1956-2012).

\begin{tabular}{|c|c|c|c|c|c|c|c|c|c|c|c|c|c|c|}
\hline \multirow[t]{3}{*}{$\begin{array}{l}\text { Hydrologic(al) } \\
\text { station }\end{array}$} & \multirow{3}{*}{$\begin{array}{l}\text { (1) Turning } \\
\text { point of high } \\
\text { yield flow } \\
\text { period } \\
\text { of "underlying } \\
\text { surface of } \\
\text { primordial } \\
\text { ecosystem" } \\
\text { (year) }\end{array}$} & \multirow{3}{*}{$\begin{array}{l}\text { (2) Turning } \\
\text { point of } \\
\text { secondary } \\
\text { failure in the } \\
\text { environment } \\
\text { of "current } \\
\text { underlying } \\
\text { surface" } \\
\text { during the } \\
\text { period of } \\
\text { low yield } \\
\text { and current } \\
\text { flow } \\
\text { (year) }\end{array}$} & \multicolumn{3}{|c|}{$\begin{array}{l}\text { The series before the } \\
\text { turning point of } \\
\text { high-yield flow } \\
\text { period in "underlying } \\
\text { surface of primordial } \\
\text { ecology" (1) }\end{array}$} & \multicolumn{2}{|c|}{$\begin{array}{l}\text { Turning point (1) and (2) } \\
\text { "current underlying } \\
\text { surface" } \\
\text { environmental } \\
\text { low-yield flow } \\
\text { period series }\end{array}$} & \multicolumn{3}{|c|}{$\begin{array}{l}\text { "current underlying surface" } \\
\text { environmental low-yield } \\
\text { flow period after } \\
\text { the turning point } \\
\text { (2) series }\end{array}$} & \multirow{2}{*}{\multicolumn{2}{|c|}{$\begin{array}{l}\text { The modified } \\
\text { series of } \\
\text { high yield } \\
\text { flow period } \\
\text { compared with } \\
\text { turning point } \\
\text { (1) and (2): } \\
\text { "current } \\
\text { underlying } \\
\text { surface" } \\
\text { environmental } \\
\text { low } \\
\text { yield } \\
\text { flow } \\
\text { period } \\
\text { series }\end{array}$}} & \multirow{2}{*}{\multicolumn{2}{|c|}{$\begin{array}{l}\text { After the } \\
\text { correction } \\
\text { of the low } \\
\text { yield flow } \\
\text { period turning } \\
\text { point (2), } \\
\text { the series is } \\
\text { higher than } \\
\text { that between } \\
\text { turning point } \\
\text { (1) and (2). } \\
\text { The "current } \\
\text { underlying } \\
\text { surface" } \\
\text { environmental } \\
\text { low yield } \\
\text { flow period } \\
\text { series }\end{array}$}} \\
\hline & & & \multicolumn{2}{|c|}{$\begin{array}{c}\text { Annual } \\
\text { runoff depth } \\
\text { mean }(\mathrm{mm})\end{array}$} & \multirow[t]{2}{*}{$\begin{array}{r}\text { Annual } \\
\text { mean } \\
\text { precipi- } \\
\text { tation } \\
(\mathrm{mm})\end{array}$} & \multirow[t]{2}{*}{$\begin{array}{r}\text { Annual } \\
\text { runoff } \\
\text { depth } \\
\text { mean } \\
(\mathrm{mm})\end{array}$} & \multirow[t]{2}{*}{$\begin{array}{r}\text { Annual } \\
\text { mean } \\
\text { precipi- } \\
\text { tation } \\
(\mathrm{mm})\end{array}$} & \multicolumn{2}{|c|}{$\begin{array}{c}\begin{array}{c}\text { Annual } \\
\text { runoff }\end{array} \\
\text { depth mean } \\
(\mathrm{mm})\end{array}$} & \multirow[t]{2}{*}{$\begin{array}{r}\text { Annual } \\
\text { mean } \\
\text { precipi- } \\
\text { tation } \\
(\mathrm{mm})\end{array}$} & & & & \\
\hline & & & $\begin{array}{r}\text { Before } \\
\text { correction }\end{array}$ & $\begin{array}{r}\text { Behind } \\
\text { correction }\end{array}$ & & & & $\begin{array}{r}\text { Befor } \\
\text { correctiol }\end{array}$ & $\begin{array}{r}\text { Behind } \\
\text { correction }\end{array}$ & & $\begin{array}{r}\text { Annua } \\
\text { runof } \\
\text { mear } \\
\text { difference } \\
(\%\end{array}$ & $\begin{array}{r}\text { Annual } \\
\text { precipi- } \\
\text { tation } \\
\text { mean } \\
\text { difference } \\
(\%)\end{array}$ & $\begin{array}{r}\text { Annual } \\
\text { runoff } \\
\text { mean } \\
\text { difference } \\
(\%)\end{array}$ & $\begin{array}{r}\text { Annual } \\
\text { precipi- } \\
\text { tation } \\
\text { mean } \\
\text { difference } \\
(\%)\end{array}$ \\
\hline MaHuYu & 1970 & 1998 & 64.5 & 59.8 & 455.0 & 39.3 & 342.0 & 32. & 48.7 & 396.0 & 52.2 & 33.0 & 23.9 & 15.8 \\
\hline GaoShiYa & 1978 & 1998 & 83.6 & 68.1 & 443.1 & 51.6 & 375.4 & 17. & 50.6 & 385.3 & 32. & 18.0 & -1.9 & 2.6 \\
\hline GaoJiaBao & 1971 & 1999 & 176.3 & 153.3 & 445.4 & 128.2 & 355.7 & 88. & 130.6 & 421.1 & 19. & 25.2 & 1.9 & 18.4 \\
\hline GaoJiaChuan & 1971 & 1999 & 134.6 & 116.4 & 449.7 & 101.5 & 355.2 & 70. & 104.0 & 430.7 & 14.7 & 26.6 & 2.5 & 21.3 \\
\hline ShenJiaWan & 1971 & 1998 & 96.1 & 72.1 & 394.1 & 48.5 & 326.1 & 28. & 56.1 & 360.6 & 48.7 & 20.9 & 15.7 & 10.6 \\
\hline
\end{tabular}

\subsection{Consistency correction of "underlying surface" of annual runoff series}

\subsubsection{Correction method}

Different ways of thinking and methods were used to correct the environmental changes of the three kinds of production and confluence mentioned above.

For the series which only changed around 2000, it was considered that the environmental conditions of the "current underlying surface" and "primordial underlying surface" were basically consistent with those of the "original ecological underlying surface" during the high-yield flow period. And the runoff series is relatively small due to the lack of "natural" amount of the measured annual runoff in that year, which is corrected by the relationship of precipitation and runoff before the turn.

For the series that only turned after 1970, Table 2 shows that although the series precipitation decreases after turning, Fig. 3 the precipitation runoff relationship curve shows that the two series are obviously larger and smaller before and after the transition. The investigation confirmed the physical causes of the disturbance of strong human activities such as persistent large-scale soil and water conservation in these areas before and after the turning year, and considered that the high-yield flow period of the "underlying surface of the original ecology" has been transformed into the period of low yield flow under the environmental condition of "current underlying surface". The correction coefficient method is used to correct the high yield flow before turning to the low yield flow condition on the "current underlying surface". Operation steps of the modified coefficient method (Li, 2003): plot the relationship between precipitation and
Table 4. Statistical table of annual precipitation and correction coefficient of Qingyangcha station.

\begin{tabular}{lrrrrrrr}
\hline$P(\mathrm{~mm})$ & 200 & 300 & 400 & 500 & 600 & 700 & 800 \\
\hline$A(\%)$ & 34.6 & 30.4 & 25.9 & 21.1 & 16.0 & 10.5 & 4.8 \\
\hline$\beta$ & 0.65 & 0.70 & 0.74 & 0.79 & 0.84 & 0.89 & 0.95 \\
\hline
\end{tabular}

runoff before and after turning year (Fig. 3). Select an annual precipitation value, Two annual runoff depth values $R_{1}$ and $R_{2}$ were found on two curves. The annual runoff attenuation rate and correction coefficient were calculated by formulas $\alpha=\left(R_{1}-R_{2}\right) / R_{1} \cdot 100 \%$ and $\beta=R_{2} / R_{1}$. The depth of runoff in the period of low yield flow on "current underlying surface"; Make annual precipitation correction coefficient Table 4; draw $\mathrm{P}-\beta$ relation curve diagram 5; check the correction coefficient of $\mathrm{P}-\beta$ relation curve, multiply by the annual runoff (depth) of the year to be revised, we can get the corresponding corrected natural annual runoff.

For the long series with two transitions around 1970 and 2000 , it is the combination of the two situations. Table 3 shows that the two short series of precipitation before the turn of 1970 and after the turn of 2000 are greater than the mean of the series between the two turning points. It is considered that it is more reasonable to unify the high yield flow before 1970 and the low yield flow after 2000 to the "current underlying surface" low yield flow period between the two turning points. The correction coefficient method is used for high yield flow correction and the relationship of precipitation and runoff between the two turning points is corrected for low yield flow after 2000 . 

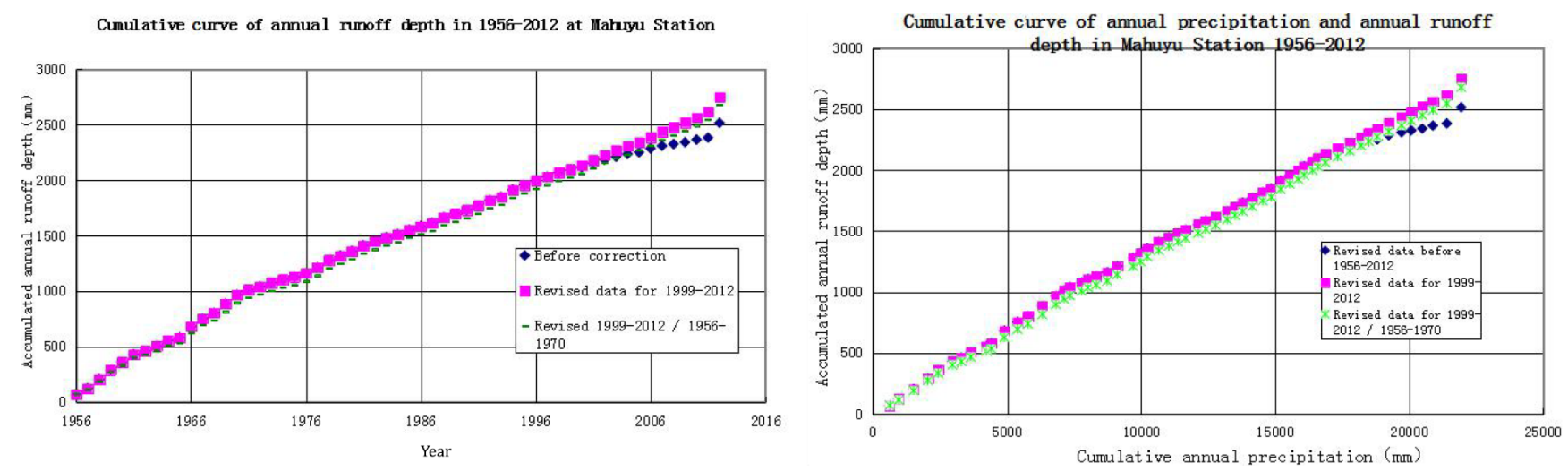

Figure 4. Annual runoff accumulation and double accumulation curve of annual precipitation runoff at Ma Huyu station.

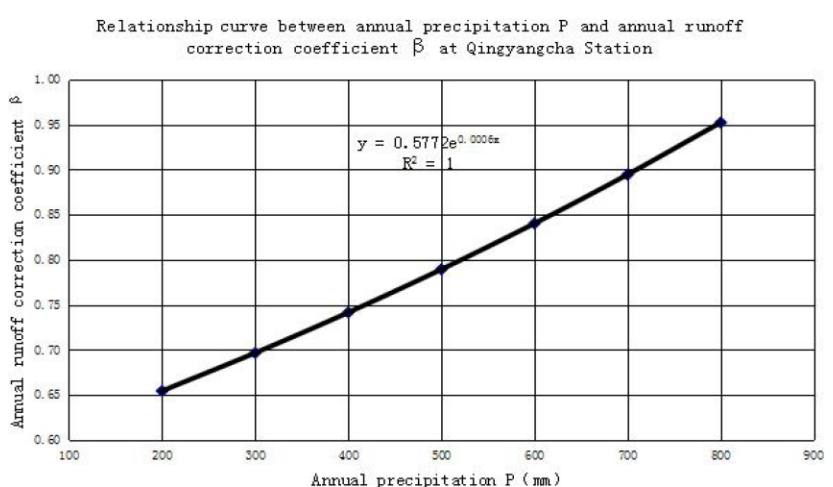

Figure 5. $\mathrm{P}-\beta$ relationship curve of Qingyangcha station.

\subsubsection{Consistency Test of modified sequences}

Plotting the double accumulation curve of the annual precipitation runoff and annual runoff single accumulation curve from 1956 to 2012 after correction, and Compared with the series of annual precipitation runoff relation curves before and after revision. From the cumulative line to the near straight line, the relative concentration degree and the correlation coefficient of the data scatter point are greatly improved, which shows that the modified sequence keeps a good consistency. The correlation coefficient of Gaoshiya station has been raised from 0.38 to 0.76 , which is shown in Figs. 1, 2, 4, 6.

\subsection{Analysis of annual runoff affected by environmental change}

\subsubsection{Analysis on Variation of annual Precipitation Series from 1956 to 2012}

The accumulated annual precipitation curve of 21 hydrologic stations, whose annual runoff series consistency has been destroyed due to the great change of underlying surfaces, shows that 17 stations have maintained a good stability of 57 years from 1956 to 2012. It is further proved that after excluding the influence of no mutation of precipitation factors and direct consumption of river water by human activities, only the consistency of the underlying surface is greatly changed and the abrupt turning system of annual runoff series is reduced. There are 4 hydrological stations, such as Qingyangcha, where the annual precipitation series is larger after 2000 than in 2000-2012 and 1956-1999, the mean value of the series is increased from $9 \%$ to $18.6 \%$, which indicates that the rainfall runoff fitting relationship before the previous year 2000 runoff series is reasonable. See Fig. 7 and Table 5 for details.

\subsubsection{Quantitative Analysis of the impact of Environmental changes such as precipitation and Human activities on Annual runoff}

Based on the average annual runoff of the series of high yield runoff in the "underlying surface of the original ecology", the series mean after the consistency correction is compared with it to judge the influence degree of the environmental change. Tables 1 and 2 show that the average effect of the corresponding two cases was $49.6 \%$ and $24.3 \%$, the highest was $76.8 \%$ and $32 \%$, and the lowest was $35.2 \%$ and $15.2 \%$. The mean influence degree of the five stations with two turns around 1970 and 2000 was $15 \%$ and $30 \%$, respectively, as shown in Table 6.

The special Wudinghe River and Beiluohe River Basin environmental changes on regional effects of the runoff are quantitatively analyzed from the author (Jing et al., 2008a, b; Jing, 2016): The effect of soil and water conservation measures on runoff decreased by more than $50 \%$ in the middle reaches of Wudinghe River, while the decrease of rainfall in the whole basin affected the runoff decrease by $76.4 \%$, and the influence of human activity accounted for $23.6 \%$,among them, the water consumption in human society accounted for $18.8 \%$, and the effect of soil and water conservation measures was $4.8 \%$. 

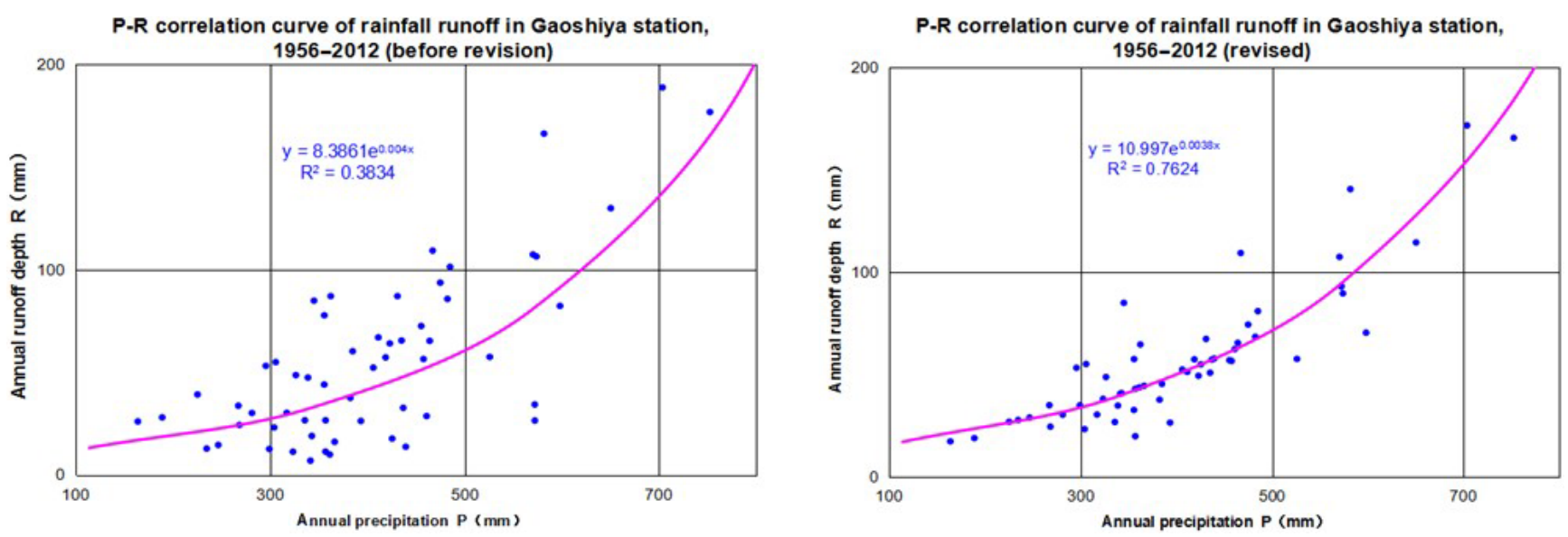

Figure 6. Comparison of precipitation runoff curve before and after correction at Gaoshiya station.
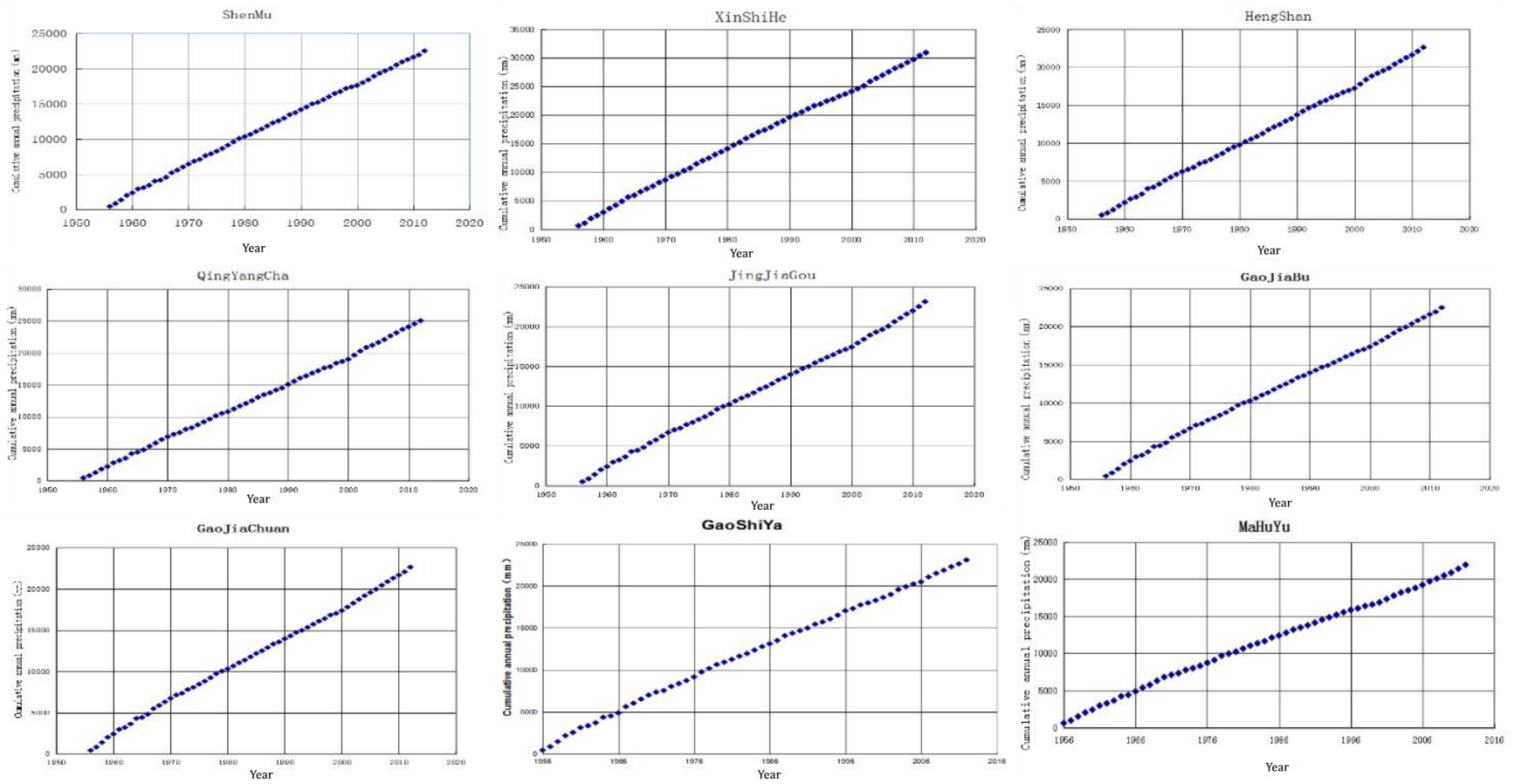

Figure 7. Accumulated curves of annual precipitation in 1956-2012 at 9 hydrologic stations such as Shenmu, Hengshan and Qingyangcha ect.

\section{Conclusion}

The underlying surface of the watershed in the hilly and gully region of the Loess Plateau in Shaanxi Province is gradually accumulated due to the long-term interactive and comprehensive disturbance of climate factors and strong human activities. The "primordial underlying surface" of most rivers in the high-yield flow period can be extended to about 2000 or so. Some rivers changed from "original ecological underlying surface" high yield flow period to low yield flow period under "current underlying surface" environment condition around 1970, and some rivers again appeared lower "cur- rent underlying surface" environment low yield flow period after 2000 or so. The consistency of the environmental conditions of the abortion and confluence of most of the rivers, and the consistency of the hydrological monitoring data sequence of the river runoff have been destroyed simultaneously. With the same order of precipitation, the yield and confluence of the watershed tend to decrease.

In the near future, the "current underlying surface" of the basin has a low yield, which is irreversible to the environmental condition of high yield in the early stage of the "underlying surface of the original ecology". Based on the principle of maintaining the consistency of the environmental 
Table 5. Statistical unit of large hydrologic station in the annual precipitation series after 2000 Units: $\mathrm{mm}$.

\begin{tabular}{|c|c|c|c|c|c|}
\hline $\begin{array}{l}\text { Hydrologic(al) } \\
\text { Station }\end{array}$ & $\begin{array}{l}\text { River } \\
\text { location }\end{array}$ & $\begin{array}{r}\text { Average annual } \\
\text { precipitation } \\
1956-1999\end{array}$ & $\begin{array}{r}\text { Average annual } \\
\text { precipitation } \\
2000-2012\end{array}$ & $\begin{array}{r}\text { After 2000, } \\
\text { the series increases } \\
\text { compared with the } \\
\text { previous series }\end{array}$ & $\begin{array}{r}\text { Increase in the } \\
\text { average value of the } \\
\text { series after } 2000 \\
\text { compared with the } \\
\text { previous series by \% }\end{array}$ \\
\hline Qingyangcha & $\begin{array}{l}\text { Wuding River tributary } \\
\text { Dali River (Middle reaches) }\end{array}$ & 424.2 & 490.4 & 66.2 & 15.6 \\
\hline Dingjiagou & $\begin{array}{l}\text { Wuding River main stream } \\
\text { (middle reaches) }\end{array}$ & 388.8 & 461.1 & 72.3 & 18.6 \\
\hline Gaojiabu & $\begin{array}{l}\text { Tu Wei River main stream } \\
\text { (middle and upper reaches) }\end{array}$ & 386.4 & 421.1 & 34.7 & 9.0 \\
\hline Gaojiachuan & $\begin{array}{l}\text { Tu Wei River main stream } \\
\text { (downstream near estuary) }\end{array}$ & 387.4 & 430.7 & 43.3 & 11.2 \\
\hline
\end{tabular}

Table 6. 1970 and 2000 annual runoff series affected by environmental changes.

\begin{tabular}{|c|c|c|c|c|c|c|c|c|c|c|c|c|}
\hline \multirow[t]{3}{*}{$\begin{array}{l}\text { Hydrologic (al) } \\
\text { station }\end{array}$} & \multicolumn{7}{|c|}{$\begin{array}{l}\text { High yield flow period of "underlying surface of } \\
\text { primordial ecology" }\end{array}$} & \multicolumn{5}{|c|}{$\begin{array}{l}\text { Low production flow period of "current underlying } \\
\text { surface" environment after } 2000\end{array}$} \\
\hline & \multirow[b]{2}{*}{ Period } & \multirow{2}{*}{$\begin{array}{r}\text { Annual } \\
\text { runoff } \\
\text { mean } \\
(\mathrm{mm})\end{array}$} & \multicolumn{2}{|c|}{$\begin{array}{l}\text { Human society } \\
\text { consumes rivers }\end{array}$} & \multicolumn{3}{|c|}{$\begin{array}{c}\text { Fixed to "current underlying } \\
\text { surface" low yield period } \\
\text { between } 1970 \text { and } 2000\end{array}$} & \multirow[b]{2}{*}{ Period } & \multicolumn{2}{|c|}{$\begin{array}{l}\text { Human society } \\
\text { consumes rivers }\end{array}$} & \multicolumn{2}{|c|}{$\begin{array}{c}\text { Fixed to "current underlying } \\
\text { surface" low yield period } \\
\text { between } 1970 \text { and } 2000\end{array}$} \\
\hline & & & $\begin{array}{r}\text { Wastage } \\
(\mathrm{mm})\end{array}$ & $\begin{array}{r}\text { Influence } \\
\text { degree }(\%)\end{array}$ & $\begin{array}{r}\text { Wastage } \\
(\mathrm{mm})\end{array}$ & $\begin{array}{r}\text { Influence } \\
\text { degree (\%) }\end{array}$ & Period & & $\begin{array}{r}\text { Wastage } \\
(\mathrm{mm})\end{array}$ & $\begin{array}{r}\text { Influence } \\
\text { degree }(\%)\end{array}$ & $\begin{array}{r}\text { Wastage } \\
(\mathrm{mm})\end{array}$ & $\begin{array}{r}\text { Influence } \\
\text { degree }(\%)\end{array}$ \\
\hline MaHuYu & 1956-1970 & 64.5 & & & -4.7 & -7.3 & 1971-1997 & 1998-2012 & & & -15.8 & -24.5 \\
\hline GaoShiYa & $1956-1978$ & 83.6 & 2.07 & 2.48 & -15.5 & -18.5 & 1979-1997 & 1998-2012 & 3.39 & 4.06 & -33.0 & -39.5 \\
\hline GaoJiaBao & 1956-1971 & 176.3 & 0.28 & 0.16 & -23.0 & -13.0 & 1972-1997 & 1999-2012 & 5.05 & 2.86 & -45.7 & -25.9 \\
\hline GaoJiaChuan & 1956-1971 & 134.6 & 0.56 & 0.42 & -18.2 & -13.5 & 1972-1997 & 1999-2012 & 6.03 & 4.48 & -30.6 & -22.7 \\
\hline ShenJiaWan & 1956-1971 & 96.1 & 1.19 & 1.24 & -24.0 & -25.0 & 1972-1997 & 1998-2012 & 4.1 & 4.27 & -40.0 & -41.6 \\
\hline
\end{tabular}

conditions of the production and confluence of the current underlying surface in the near future, the hydrological observation data of the river should be revised to a unified basic standard, so that the hydrological sequence data can keep the consistency of the source "underlying surface" of the hydrological sequence. It is more meaningful in practical application.

In the region controlled by most rivers in the hilly and gully of the Loess Plateau in northern Shaanxi, the annual precipitation has maintained the stability of the 57 years series of 1956-2012 without systematic abrupt changes. After 2000 , the annual precipitation in the whole basin of TuWeihe river was about $10 \%$ larger a year, over the middle reaches of Wudinghe river, there are about $17 \%$, while the annual precipitation in the lower reaches of Wudinghe river keeps the stability of 57 years series.

The correction method in this paper can only meet the accuracy of the consistency correction of annual runoff series when the regional water resources evaluation is satisfied. The difficulty is how to discretize the revised data as random events occur, which should be concretely analyzed, selected and used.
Data availability. The meteorological data used in the previous study came from the China Meteorological Network (http://data. cma.cn, last access: 26 June 2018), and the agricultural irrigation, industrial and urban domestic water use data came from the Shaanxi Water Resources Bulletin (http://slt.shaanxi.gov.cn/ sxmwr-zxfw-dfkj-3-show-93956, last access: 26 June 2018). The hydrological data were collected from the the Yellow River Water Conservancy Commission (YRWCC), Ministry of Water Resources of China and the Hydrology and Water Resources Survey Bureau of Shaanxi Province. These data are proprietary or confidential in nature and may only be provided with restrictions.

Author contributions. JY conceived the idea, data analysis and wrote the manuscript; $\mathrm{ZZ}$ supervised the data analysis and writing process. Both authors have read and agreed to the published version of the manuscript.

Competing interests. The authors declare that they have no conflict of interest.

Special issue statement. This article is part of the special issue "Hydrological processes and water security in a changing world". 
It is a result of the 8th Global FRIEND-Water Conference: Hydrological Processes and Water Security in a Changing World, Beijing, China, 6-9 November 2018.

Financial support. This research has been supported by the the National Key Research and Development Program of China (grant no. 2016YFC0402405).

\section{References}

Hui, Y. Y., Liu, T. H., and Tong, X. Q.: Water and sediment changes in Wuding River, Yanhe River and Qingjian River and their development trend forecast, Yellow River Water and Sediment Change Research Foundation, China, Dissertation, 1993 (in Chinese).

Jing, Y., Chen, F. L., and Ge, F. L.: Study on Idiosyncrasy of Water and Sediment on Area headstream in Beiluohe Watershed, Hydrology and Water Resources Survey of Shaanxi Province, Shaanxi, China, Report, 2008a (in Chinese).

Jing, Y., Chen, F. L., Ge, F. L., and Gu, M. X.: Analysis of characteristics of Water and sediment in Source area of North Luohe River, Hydrology, 030, 92-96, https://doi.org/10.3969/j.issn.10000852.2010.04.023, 2010b (in Chinese).

Jing, Y., Ge, F. L., and Tian, H. W.: Department of Water Resources of Shaanxi Province, Water Resources Bulletin (20002016), Shaanxi, China, Report, 2016c (in Chinese).

Jing, Y., Li, Z. Y., and Pang, L.: Technical methods of Shaanxi Provincial Hydrological calculation Manual, Shaanxi Provincial Bureau of Hydrology and Water Resources Survey, Shaanxi, China, Report, 2017d (in Chinese).
Jing, Y.: Analysis on flow consistency and effect of human being in Wu Dinghe River, in: 2008 Academic Forum on Water Ecology Monitoring and Analysis, Shenyang, China, 2 December 2008, 272-276, 2008 (in Chinese).

Li, Y. Y.: Work document for the preparation of the national water resources comprehensive planning, The office of the leading group of the national water resources comprehensive planning work, Beijing, China, Report, 2003 (in Chinese).

Peng, R. S.: A preliminary study on the correction of water and sediment data, Study on water resources, 5, 368-378, https://doi.org/10.12677/JWRR.2016.54043, 2016 (in Chinese).

Wang, G. Q., Jia, X. A., Chen, J. N., Zhang, Y., and Li, H. B.: Interference point analysis of the significant influence of human activities on Hydrologic sequence, Northwest Water Resources and Water Engineering, 12, 13-15, https://doi.org/10.3969/j.issn.1672-643X.2001.03.004, 2001 (in Chinese).

Wang, G. Q., Zhang, J. Y., Liu, J. F., and He, R. M.: Quantitative Analysis of the effects of Climate change and Human activities on runoff, China Water, 2, 55-58, https://doi.org/10.3969/j.issn.1000-1123.2008.02.016, 2012 (in Chinese).

Zhang, A. J., Wang, B. D., and Cao, L.: Summary of studies on the contribution of climate change and human activities to runoff, Northeast China Water Conservancy and Hydropower, 1, 7-8, https://doi.org/10.14124/j.cnki.dbslsd22-1097.2012.01.001, 2012 (in Chinese).

Zhu, H. F., Zhao, W. W., Kang, M. Y., and Guo, W. W.: Analysis on Obvious Disturbing Point in Time Variation Process of Sediment Discharge of the Yanhe River, Yellow River, 8, 8081, https://doi.org/10.3969/j.issn.1000-1379.2008.08.036, 2008 (in Chinese). 